\title{
FAKTOR-FAKTOR YANG MEMPENGARUHI PEREMPUAN BERPENDIDIKAN TINGGI BERPERAN SEBAGAI PENGAMBIL KEPUTUSAN DALAM KELUARGA DI KELURAHAN ISOLA
}

\author{
Elis Setiawati, Elly Malihah, Siti Komariah \\ Universitas Pendidikan Indonesia \\ Jl. Dr.Setiabudi 229 Bandung 40154, Jawa Barat, Indonesia \\ Email: elissetiawati28@gmail.com
}

\begin{abstract}
Abstrak Perempuan memiliki pengetahuan yang luas dan tingkat pendidikan yang tinggi, maka peran mereka secara mikro dalam keluarga akan tinggi pula. Seperti dalam kehidupan berkeluarga, sering kali kita menjumpai masalah pengambilan keputusan tentang hal-hal yang berkaitan dengan kepentingan para anggota keluarga. Pengambilan keputusan yang dilakukan oleh suami maupun istri pasti akan berpengaruh pada tindakan yang akan dilakukan kelak. Perempuan atau istri yang memiliki pendidikan yang tinggi pasti akan ikut berperan dalam pengambilan keputusan dalam keluarga. Artikel ini bertujuan untuk menjelaskan apa saja faktor yang dapat mempengaruhi perempuan berpendidikan tinggi berperan sebagai pengambil keputusan dalam keluarga. Penelitian ini menggunakan pendekatan kualitatif dengan metode deskriptif. Pengumpulan data menggunakan teknik observasi, wawancara, studi dokumentasi dan studi literatur. Informan penelitian terdiri dari perempuan berpendidikan tinggi beserta keluarga (suami dan anak) dan pengurus PKK Kelurahan Isola. Hasil penelitian ini memaparkan tentang Faktor pendorong perempuan bertindak sebagai pengambil keputusan dalam keluarga terdapat faktor intern dan ekstern yang mempengaruhinya.

Kata kunci: keluarga, pengambilan keputusan, perempuan berpendidikan tinggi
\end{abstract}

\section{PENDAHULUAN}

Jumlah perempuan yang memiliki tingkat pendidikan tinggi di Kelurahan Isola sebanyak 9,63\% untuk sarjana dan 5,56\% untuk sarjana muda dari populasi jumlah perempuan di Kelurahan Isola. Semakin tinggi tingkat pendidikan masyarakat, maka pola pikir masyarakat pun akan berubah. Begitu pun dengan kaum perempuan sekarang ini, banyak dari mereka yang telah mengenyam pendidikan tinggi dan memasuki dunia kerja sehingga dapat bersaing dengan laki-laki dalam ranah publik.

Seperti penelitian yang telah dilakukan oleh Nilakusmawati dan Susilawati (2012) dalam jurnal ilmiahnya yang berjudul studi faktor-faktor yang mempengaruhi wanita bekerja di kota Denpasar menjelaskan bahwa wanita yang memilih untuk bekerja lebih banyak berasal dari tingkat pendidikan perguruan tinggi. Dengan pendidikannya, keinginan perempuan untuk mengembangkan dirinya semakin besar dengan upaya aktualisasi diri, sehingga pendidikannya dapat dimanfaatkan untuk diterapkan di masyarakat.

Pendidikan tinggi yang di peroleh perempuan akan mempengaruhi perannya dalam keluarga dan masyarakat. Khususnya dalam keluarga terdapat peran pengambil keputusan yang mana peran tersebut bertugas memberikan keputusan untuk apa yang akan dilakukan atau kerjakan oleh para anggota keluarga. Perempuan berpendidikan tinggi memiliki kesempatan yang cukup tinggi untuk bertindak sebagai pengambil keputusan dalam keluarga. Maka, tidak heran jika perempuan dapat mendominasi lakilaki dalam hal keputusan-keputusan yang diambil dalam keluarga. Dengan pengetahuan dan wawasan perempuan yang luas perempuan dapat bertindak sebagai pengambil keputusan dalam keluarga.

Pada kenyataannya, memang peran perempuan berpendidikan tinggi dalam keluarga mengalami peningkatan yang cukup signifikan. Ini terlihat bahwa di Kelurahan Isola terdapat banyak perempuan/ istri memiliki pendidikan tinggi yang berperan aktif dalam pengambilan keputusan keluarga. Akan tetapi, hal ini masih terbatas untuk perannya dalam ranah publik. Perempuan Kelurahan Isola lebih banyak bertindak sebagai pengambil keputusan untuk ranah domestik. Di samping terdapat pembagian peran dalam hal pengambilan keputusan keluarga, perempuan berpendidikan tinggi dan suami lebih banyak melakukan musyawarah sebelum mengambil keputusan dalam keluarga. 
Untuk mengetahui peran perempuan berpendidikan tinggi dalam proses pengambilan keputusan keluarga di Kelurahan Isola, maka peneliti tertarik untuk mengetahui dan meneliti hal tersebut. Diperlukan studi lapangan yang dilakukan untuk mengetahui faktor apa saja yang mendorong perempuan untuk bertindak sebagai pengambil keputusan dalam keluarga.

\section{STUDI LITERATUR}

Sholikah (2014, hlm. 22) mengungkapkan konsep ekonomi dalam pengambilan keputusan yaitu bahwa "pengambilan keputusan adalah proses perilaku orang ketika memilih produk atau jasa mana yang akan di konsumsi”. Pengambilan keputusan merupakan alat yang digunakan konsumen untuk menilai dan memilih di antara alternatif produk yang mungkin dapat memuaskan kebutuhan mereka. Pengambilann keputusan merupakan permulaan dari aktivitas manusia yang sadar dan terarah,baik secara individu, kelompok atau lembaga, sehingga pengambilan keputusan menjadi aspek yang penting dalam suatu pengelolaan atau manajemen. Sedangkan aspekaspek penentu dalam mengambil keputusan yaitu:

a. Jenis pekerjaan rumah tangga; pekerjaan fisik dan sosial.

b. Kebutuhan keluarga; kebutuhan pokok dan tambahan.

c. Perlengkapan dan fasilitas yang ada dalam keluarga.

d. Waktu dan tenaga yang tersedia.

e. Sifat pekerjaan; rutin dan insidental.

f. Rasa aman dalam melaksanakan pekerjaan keluarga. (Sholikah, 2014, hlm. 23)

Dalam kehidupan sehari-hari, keluarga sering kali dihadapkan pada masalah pengambilan keputusan tentang hal-hal yang berkaitan dengan kepentingan anggota keluarga. Hubungan antara pola pengambilan keputusan dan struktur kekuasaan dalam keluarga, Sholikah (2014, hlm. 23) menyatakan bahwa "pola pengambilan keputusan (decision making) dalam suatu keluarga menggambarkan bagaimana struktur/pola kekuasaan dalam keluarga tersebut". Bahkan menurut Scanzoni dan Scanzoni (dalam Sajogyo, 1985, hlm. 36) metode yang sering digunakan "untuk mengukur kekuasaan dalam perkawinan/keluarga adalah dengan menanyakan kapada responden tentang siapa yang mengambil keputusan terakhir tentang sejumlah persoalan dalam keluarga". Keputusankeputusan dalam keluarga, di antaranya:

a. Keputusan yang diambil harus dirundingkan lebih dahulu dengan anggota keluarga yang lain karena dapat menimbulkan konflik.

b. Konflik muncul setelah ada keputusan meskipun telah direncanakan sebelumnya.

c. Keputusan yang harmonis, supaya menimbulkan keputusan bagi seluruh anggota keluarga dan angan mementingkan diri sendiri.

d. Keputusan yang Tergesa-gesa sering kali menimbulkan putusan yang buruk.

e. Keputusan yang baik tergantung pada pengetahuan tentang faktor-faktor yang termasuk dalam situasi.

f. Untuk memperoleh keputusan yang baik hendaklah mengumpulkan data-data terlebih dahulu, menganalisa data, mempertimbangkan tujuan dalam kaitannya dengan data-data. (Sholikah, 2014, hlm. 24)

Peran pengambilan keputusan dalam keluarga dipengaruhi oleh norma yang diyakini oleh suami dan istri. Dalam hal ini norma yang diyakini di sini yaitu laki-laki atau suami harus lebih dominan dibandingkan istri dalam pengambilan keputusan. Hal ini terkait dengan peran suami sebagai pencari nafkah utama, menjadi suami paling menguasai sumber daya keluarga. Sehingga dalam pola hubungan yang tradisional, maka suami yang paling menentukan dalam pengambilan keputusan keluarga.

Berkaitan dengan perempuan/istri sebagai pengambil keputusan, sampai saat ini masih terdapat anggapan bahwa perempuan tidak mempunyai peranan dalam pengambilan keputusan di dalam maupun di luar keluarga. Norma yang pada umumnya diakui menyatakan bahwa yang paling menentukan dalam pengambilan keputusan adalah kaum laki-laki /suami.

Pada kenyataannya, terdapat berbagai variasi tentang soal pengambilan keputusan dalam keluarga. Adakalanya perempuan/istri tidak diikutsertakan, namun adakalanya justru wanita yang menentukan dalam pengambilan keputusan. Banyak pula keputusan dalam keluarga dilakukan bersama-sama antara suami dan istri. Berbagai faktor mempengaruhi peranan perempuan/istri dalam persoalan pengambilan keputusan, antara lain seperti adanya pemikiran di masyarakat mengenai keterkaitannya dengan budaya yang ada. Sehingga membedakan dua sektor kegiatan dalam masyarakat, yaitu sektor publik dan sektor domestik. Sektor domestik adalah bidang untuk perempuan/istri, yaitu lingkungan di rumah tangga saja, sedangkan sektor 
publik adalah bidang untuk laki-laki/suami yaitu di luar lingkungan rumah tangga sebagai pencari nafkah untuk keluarga.

Selain itu ada faktor-faktor lain yang dianggap mempengaruhi peranan perempuan/istri dalam pengambilan keputusan (Sajogyo, 1985), yaitu:

a. Proses sosialisasi, dalam proses sosialisasi individu mempelajari kebiasaan, sikap, ide-ide, pola-pola, nilai dan tingkah laku dalam masyarakat dimana ia hidup. Keluarga sebagai lingkungan sosial pertama memperkenalkan perbedaan antara anak laki-laki dan perempuan mulai dari cara memperlakukan, cara bersikap, peran-peran yang diperkenalkan dan harus dilakukan sebagai anak laki-laki dan perempuan. Hal-hal yang seperti inilah berpengaruh terhadap peranan anak laki-laki maupun perempuan dalam mengambil keputusan.

b. Pendidikan, dengan pendidikan yang dimiliki akan berpengaruh terhadap cara berpikir yang lebih luas berdasarkan pengalaman dan wawasan yang mungkin tidak didapat dalam keluarga.

c. Latar belakang perkawinan, pengaruh latar belakang perkawinan terhadap pengambilan keputusan istri dalam keluarga adalah kesepakatan antara suami - istri untuk membentuk sebuah keluarga yang siap menerima satu sama lain, yang diawali dengan perkenalan dan kesamaan tujuan ke depan.

d. Kedudukan dalam masyarakat, kedudukan yang dimiliki perempuan dalam masyarakat secara tidak langsung akan terbawa dalam keluarga dan berpengaruh terhadap perannya dalam keluarga.

Dalam perspektif proses orientasi, pengambilan keputusan dipengaruhi oleh tiga elemen. Pertama; Konteks merupakan sumber yang nampak dan tidak nampak, sikap, dan sejarah pasangan yang memiliki peranan dalam proses pengambilan keputusan keluarga. Kedua; Proses merupakan interaksi yang terjadi antara pasangan suami-istri dalam proses pengambilan keputusan keluarga. Ketiga; Hasil menggambarkan perilaku dari pasangan suami istri setelah proses pengambilan keputusan keluarga berakhir. Ketiga elemen ini saling berkaitan satu sama lain sehingga keputusan yang akan diambil dalam keluarga dapat diputuskan. Dengan demikian dapat dilihat siapa yang berpengaruh dalam keluarga tersebut.

\section{METODE PENELITIAN}

Penelitian ini merupakan penelitian kualitatif dengan menggunakan Metode deskriptif. Penelitian di lakukan di Kelurahan Isola Rw 07 Cilimus. Total informan dalam penelitian ini sebanyak 10 orang. Jumlah tersebut terdiri dari 5 orang ibu rumah tangga berpendidikan tinggi yang merupakan informan pokok, 2 orang suami dan 2 orang anak dari ibu rumah tangga tersebut, serta 1 orang yang merupakan ibu PKK di Kelurahan Isola yang berada dekat dengan ibu rumah tangga berpendidikan tinggi sebagai informan pendukung dalam penelitian. Jumlah tersebut sudah dikatakan cukup untuk mewakili jawaban dari setiap rumusan masalah penelitian, karena para informan sudah memberikan informasi yang diperlukan oleh peneliti untuk penelitian ini.

Sampling yang digunakan dalam pendekatan kualitatif ini yaitu purposive sampling dan snowball sampling. Artinya, subjek penelitian relatif sedikit dan dipilih menurut tujuan penelitian namun subjek penelitian dapat terus bertambah sesuai keperluannya. Snowball sampling dilakukan karena informasi tidak cukup dari satu sumber saja, nantinya informan akan menunjuk sumber-sumber lain yang dapat memberikan informasi begitu pun seterusnya hingga informasi berada pada titik jenuh. Hasil penelitian yang diperoleh melalui teknik observasi, wawancara, studi dokumentasi, dan studi literatur.

\section{HASIL DAN PEMBAHASAN}

Keterlibatan perempuan dalam sektor pengambilan keputusan dalam keluarga tidak lepas dari beberapa hal yang mendasarinya. Banyak alasan seorang untuk bertindak sebagai pengambil keputusan. Oleh karena itu, dalam penelitian ini memaparkan tentang faktor pendorong peran perempuan berpendidikan tinggi terhadap pengambilan keputusan dalam keluarga. Faktor tersebut tidak hanya datang dari dalam diri perempuan, melainkan juga faktor lain yang datang dari luar. Dengan demikian, faktor pendorong perempuan berpendidikan tinggi untuk mengambil keputusan dalam keluarga terbagi menjadi dua, yaitu faktor intern dan faktor ekstern.

Faktor intern yang mempengaruhi perempuan dalam pengambilan keputusan keluarga di Kelurahan Isola adalah ada rasa tanggung jawab istri dalam melakukan pengambilan keputusan keluarga, yang mana suami telah mengamanahkan tugas dan 
istri merasa itu sebagai kewajiban yang harus dijalankan. Sebab pembagian peran dalam keluarga menentukan pengambilan keputusan seseorang untuk peran yang nantinya akan dilakukan.

Kemudian pendidikan istri juga mempengaruhi dalam pengambilan keputusan keluarga. Dengan pendidikan istri lebih paham akan tugas dan perannya dalam keluarga, sehingga akan lebih banyak membantu suami dalam pengambilan keputusan keluarga. Hal ini di ungkapkan oleh ibu Yani dalam wawancaranya bahwa ketika istri memiliki pendidikan tinggi, maka pengetahuan dan wawasannya luas, sehingga istri dapat ikut berperan aktif dan berdiskusi dengan suami perihal putusanputusan dalam keluarga. Akan tetapi, istri dengan pendidikan tinggi juga dapat mendominasi atau menguasai suami dalam pengambilan keputusan keluarga jika pendidikan suami lebih rendah dari istri. Berdasarkan hasil observasi dan wawancara dengan para informan baik pokok maupun pendukung dapat terlihat bahwa ketika istri dan suami memiliki tingkat pendidikan yang sama/setingkat pengambilan keputusan dalam keluarga lebih banyak di lakukan atas kesepakatan bersama yang dilakukan segan cara berdiskusi, musyawarah, dan mufakat.

Selain pendidikan, kontribusi ekonomi dalam keluarga juga banyak mempengaruhi keterlibatan perempuan dalam pengambilan keputusan keluarga. Perempuan yang bekerja pasti lebih mandiri di bandingkan dengan perempuan yang tidak bekerja. Perempuan yang tidak bekerja akan bergantung ke suami dalam hal pembiayaan hidup keluarga. Sehingga pengambilan keputusan dalam hal kegiatan ekonomi lebih banyak suami yang putuskan.

Sedangkan untuk faktor ekstern-nya yaitu karena adanya kepercayaan suami untuk istri dalam mengambil keputusan keluarga. Selain itu, pendidikan yang di sandang oleh istri tinggi, maka wawasan maupun pengalaman dapat mempengaruhi seseorang dalam mengambil sebuah keputusan. Di kelurahan Isola suami yang memiliki istri yang pendidikannya tinggi lebih banyak mengajak diskusi dalam pengambilan keputusan keluarga. Selain itu, kedudukan istri dalam keluarga juga dapat menjadikannya sebagai pengambil keputusan. Istri sebagai ibu rumah tangga di rumah lebih banyak bertindak sebagai pengambil keputusan dalam urusan rumah tangga (domestik). Sedangkan istri yang bekerja atau berperan ganda tidak hanya pengambilan keputusan dalam ranah domestik saja yang di urusi, tapi keputusan dalam ranah publik juga ikut memegang peranan penting dalam keluarga.

Dalam sudut pandang masyarakat perempuan berpendidikan tinggi memiliki kedudukan yang tinggi pula dalam kehidupan sosialnya. Perempuan akan lebih dihargai, di sanjung, dan di hormati oleh masyarakat karena memiliki pengetahuan dan wawasan yang luas, sehingga dalam keluarga pun perempuan akan lebih di hargai keberadaannya terlebih dalam pengambilan keputusan keluarga.

\section{Tabel 1. Faktor Pendorong Perempuan Berpendidikan Tinggi dalam Pengambilan Keputusan Keluarga}

\begin{tabular}{|c|c|c|}
\hline No & Faktor Intern & Faktor Ekstern \\
\hline \multirow[t]{2}{*}{1} & Adanya kewajiban dan & Kepercayaan \\
\hline & $\begin{array}{l}\text { rasa tanggung jawab } \\
\text { dari istri atas peran } \\
\text { yang dijalankannya, } \\
\text { sehingga ia dapat } \\
\text { bertindak sebagai } \\
\text { pengambil keputusan } \\
\text { dalam keluarga. }\end{array}$ & $\begin{array}{l}\text { suami kepada istri } \\
\text { untuk menjalankan } \\
\text { tugas sesuai dengan } \\
\text { peran, sehingga istri } \\
\text { dapat mengambil } \\
\text { keputusan sendiri } \\
\text { tanpa campur tangan } \\
\text { suami. }\end{array}$ \\
\hline \multirow[t]{8}{*}{2} & $\begin{array}{l}\text { Pendidikan tinggi istri } \\
\text { berpengaruh terhadap } \\
\text { pengambilan }\end{array}$ & $\begin{array}{l}\text { Kedudukan istri } \\
\text { dalam keluarga juga } \\
\text { dapat menjadikannya }\end{array}$ \\
\hline & $\begin{array}{l}\text { keputusan keluarga, } \\
\text { istri lebih paham akan }\end{array}$ & $\begin{array}{l}\text { sebagai pengambil } \\
\text { keputusan. }\end{array}$ \\
\hline & tugas dan perannya & \\
\hline & sehingga akan lebih & \\
\hline & banyak membantu & \\
\hline & suami dalam & \\
\hline & pengambilan & \\
\hline & keputusan keluarga. & \\
\hline \multirow[t]{5}{*}{3} & Memiliki wawasan dan & Masyarakat \\
\hline & pengetahuan yang & menganggap \\
\hline & lebih dari suami & perempuan \\
\hline & $\begin{array}{l}\text { sehingga keputusan di } \\
\text { buat oleh perempuan. }\end{array}$ & $\begin{array}{l}\text { berpendidikan tinggi } \\
\text { memiliki kedudukan }\end{array}$ \\
\hline & & $\begin{array}{ll}\text { yang tinggi pula } \\
\text { dalam } \\
\text { sosialnya. }\end{array}$ \\
\hline \multirow[t]{4}{*}{4} & Kontribusi $\quad$ ekonomi & Pekerjaan perempuan \\
\hline & $\begin{array}{l}\text { dalam keluarga juga } \\
\text { banyak mempengaruhi } \\
\text { keterlibatan }\end{array}$ & $\begin{array}{l}\text { dalam sektor publik, } \\
\text { akan berpengaruh } \\
\text { terhadap }\end{array}$ \\
\hline & perempuan dalam & pengambilan \\
\hline & $\begin{array}{l}\text { pengambilan } \\
\text { keputusan keluarga. }\end{array}$ & $\begin{array}{l}\text { keputusan keluarga, } \\
\text { tidak hanya ranah } \\
\text { domestik saja. }\end{array}$ \\
\hline
\end{tabular}

Sumber: diolah peneliti berdasarkan data penelitian tahun 2017

Mulyo dkk, (1998) mengungkapkan bahwa: Peranan wanita sangat kuat dalam pengambilan keputusan untuk aktivitas produksi dan aktivitas rumah tangga. Wanita dari keluarga miskin 
cenderung lebih berperan dalam mengambil keputusan dibandingkan suaminya. Hasil penelitian menunjukkan bahwa besar kecilnya pendapatan istri tidak mempengaruhi besar kecilnya keterlibatan wanita dalam pengambilan keputusan usaha tani

Berdasarkan penelitian Mustika dkk, mengenai pendidikan wanita dan pendidikan pria, menunjukkan bahwa "jika semakin tinggi pendidikan wanita maka akan berpengaruh terhadap pengambilan keputusan oleh wanita menjadi bertambah. Semakin tua umur pria maka pengambilan keputusan oleh wanita semakin akan bertambah akan tetapi semakin bertambahnya umur wanita akan menyebabkan pengambilan keputusan oleh wanita menjadi berkurang".

Selain itu ada faktor-faktor lain yang dianggap mempengaruhi peranan perempuan/istri dalam pengambilan keputusan (Sajogyo, 1985), yaitu:

a. Proses sosialisasi, dalam proses sosialisasi individu mempelajari kebiasaan, sikap, ide-ide, pola-pola, nilai dan tingkah laku dalam masyarakat dimana ia hidup. Keluarga sebagai lingkungan sosial pertama memperkenalkan perbedaan antara anak laki-laki dan perempuan mulai dari cara memperlakukan, cara bersikap, peran-peran yang diperkenalkan dan harus dilakukan sebagai anak laki-laki dan perempuan. Hal-hal yang seperti inilah berpengaruh terhadap peranan anak laki-laki maupun perempuan dalam mengambil keputusan.

b. Pendidikan, dengan pendidikan yang dimiliki akan berpengaruh terhadap cara berpikir yang lebih luas berdasarkan pengalaman dan wawasan yang mungkin tidak didapat dalam keluarga.

c. Latar belakang perkawinan, pengaruh latar belakang perkawinan terhadap pengambilan keputusan istri dalam keluarga adalah kesepakatan antara suamiistri untuk membentuk sebuah keluarga yang siap menerima satu sama lain, yang diawali dengan perkenalan dan kesamaan tujuan ke depan.

d. Kedudukan dalam masyarakat, kedudukan yang dimiliki perempuan dalam masyarakat secara tidak langsung akan terbawa dalam keluarga dan berpengaruh terhadap perannya dalam keluarga.

Keterlibatan perempuan dalam sektor pengambilan keputusan dalam keluarga tidak lepas dari beberapa hal yang mendasarinya. Banyak alasan seorang untuk bertindak sebagai pengambil keputusan. Oleh karena itu, dalam penelitian ini memaparkan tentang faktor pendorong peran perempuan berpendidikan tinggi terhadap pengambilan keputusan dalam keluarga. Faktor tersebut tidak hanya datang dari dalam diri perempuan, melainkan juga faktor lain yang datang dari luar. Dengan demikian, faktor pendorong perempuan berpendidikan tinggi untuk mengambil keputusan dalam keluarga terbagi menjadi dua, yaitu faktor intern dan faktor ekstern.

Faktor intern yang mempengaruhi perempuan dalam pengambilan keputusan keluarga di Kelurahan Isola adalah ada rasa tanggung jawab istri dalam melakukan pengambilan keputusan keluarga, yang mana suami telah mengamanahkan tugas dan istri merasa itu sebagai kewajiban yang harus dijalankan. Sebab pembagian peran dalam keluarga menentukan pengambilan keputusan seseorang untuk peran yang nantinya akan dilakukan.

Kemudian pendidikan istri juga mempengaruhi dalam pengambilan keputusan keluarga. Dengan pendidikan istri lebih paham akan tugas dan perannya dalam keluarga, sehingga akan lebih banyak membantu suami dalam pengambilan keputusan keluarga. Akan tetapi, istri dengan pendidikan tinggi juga dapat mendominasi atau menguasai suami dalam pengambilan keputusan keluarga jika pendidikan suami lebih rendah dari istri. Berdasarkan hasil observasi dan wawancara dengan para informan baik pokok maupun pendukung dapat terlihat bahwa ketika istri dan suami memiliki tingkat pendidikan yang sama/setingkat pengambilan keputusan dalam keluarga lebih banyak di lakukan atas kesepakatan bersama yang dilakukan segan cara berdiskusi, musyawarah, dan mufakat.

Selain pendidikan, kontribusi ekonomi dalam keluarga juga banyak mempengaruhi keterlibatan perempuan dalam pengambilan keputusan keluarga. Perempuan yang bekerja pasti lebih mandiri di bandingkan dengan perempuan yang tidak bekerja. Perempuan yang tidak bekerja akan bergantung ke suami dalam hal pembiayaan hidup keluarga. Sehingga pengambilan keputusan dalam hal kegiatan ekonomi lebih banyak suami yang putuskan.

Sedangkan untuk faktor ekstern-nya yaitu karena adanya kepercayaan suami untuk istri dalam mengambil keputusan keluarga. Selain itu, pendidikan yang di sandang oleh istri tinggi, maka wawasan maupun pengalaman dapat mempengaruhi seseorang dalam mengambil sebuah keputusan. Di kelurahan Isola suami yang memiliki istri yang pendidikannya tinggi lebih banyak mengajak diskusi dalam pengambilan keputusan keluarga. Selain itu, kedudukan istri dalam keluarga juga dapat menjadikannya sebagai pengambil keputusan. Istri sebagai ibu rumah tangga di rumah lebih banyak bertindak sebagai pengambil keputusan dalam urusan rumah tangga (domestik). Sedangkan istri yang bekerja atau berperan ganda tidak hanya pengambilan keputusan dalam ranah domestik saja 
yang di urusi, tapi keputusan dalam ranah publik juga ikut memegang peranan penting dalam keluarga.

Dalam sudut pandang masyarakat perempuan berpendidikan tinggi memiliki kedudukan yang tinggi pula dalam kehidupan sosialnya. Perempuan akan lebih dihargai, di sanjung, dan di hormati oleh masyarakat karena memiliki pengetahuan dan wawasan yang luas, sehingga dalam keluarga pun perempuan akan lebih di hargai keberadaannya terlebih dalam pengambilan keputusan keluarga.

\section{KESIMPULAN}

Faktor pendorong perempuan berpendidikan tinggi bertindak sebagai pengambil keputusan dalam keluarga yaitu terdapat faktor intern dan ekstern. Faktor intern di antaranya, adanya kewajiban dan rasa tanggung jawab dari istri atas peran yang dijalankannya, sehingga ia dapat bertindak sebagai pengambil keputusan dalam keluarga, pendidikan tinggi istri berpengaruh terhadap pengambilan keputusan keluarga, istri lebih paham akan tugas dan perannya dalam keluarga, sehingga akan lebih banyak membantu suami dalam pengambilan keputusan keluarga, memiliki wawasan dan pengetahuan yang lebih dari suami sehingga keputusan di buat oleh perempuan, dan Kontribusi ekonomi dalam keluarga juga banyak mempengaruhi keterlibatan perempuan dalam pengambilan keputusan keluarga. sedangkan untuk faktor ekstern sendiri yaitu kepercayaan suami kepada istri untuk menjalankan tugas sesuai dengan peran, sehingga istri dapat mengambil keputusan sendiri tanpa campur tangan suami, kedudukan istri dalam keluarga juga dapat menjadikannya sebagai pengambil keputusan, Masyarakat menganggap perempuan berpendidikan tinggi memiliki kedudukan yang tinggi pula dalam kehidupan sosialnya, dan pekerjaan perempuan dalam sektor publik, akan berpengaruh terhadap pengambilan keputusan keluarga, tidak hanya ranah domestik saja.

\section{REFERENSI}

Sajogyo, Pudjiwati. (1985). Peranan Wanita dalam Perkembangan Masyarakat Desa. Jakarta: CV. Rajawali

Mulyo, Jangkung dan Jamhari. (1998). Peranan Wanita dalam Peningkatan Pendapatan dan Pengambilan Keputusan. Agroekonomi, (1).
Nilakusmawati, D. P. E. \& Susilawati, M. (2012). Studi Faktor-Faktor yang Mempengaruhi Wanita Bekerja di Kota Denpasar. Piramida: Jurnal Kependudukan dan Pengembangan Sumber Daya Manusia, VIII (1), 26-31.

Sholikah, Himayatus. (2014). Peran Perempuan sebagai Pengambil Keputusan dalam Keluarga Miskin. (Skripsi). Fakultas Ilmu sosial dan Ilmu Politik, Universitas Sebelas Maret, Surakarta. 